\title{
Analysis of Students' Creative Thinking in Solving Cuboid Problems
}

\section{Anisah Saida | Muhammad Ikram | Salwah}

How to cite : Saida, A, Ikram, M, \& Salwah, .Analysis of Students' Creative Thinking in Solving Cuboid Problems. International Journal of Progressive Mathematics Education. 1(2)104-116. https://doi.org/10.22236/ijopme.v1i2.7307

To link to this article : https://doi.org/10.22236/ijopme.v1i2.7307

(C)2021. The Author(s). This open access article is distributed under a Creative Commons Attribution (CC BY-SA) 4.0 license.

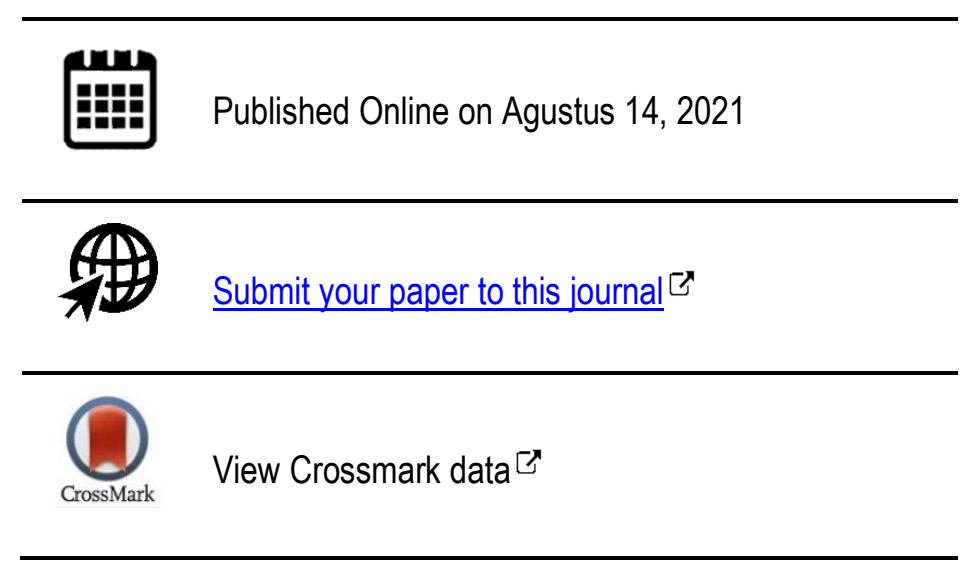




\title{
Analysis of Students' Creative Thinking in Solving Cuboid Problems
}

\author{
Anisah Saida1, Muhammad Ikram (D) 1, Salwah $^{1}$
}

Received: February 20,2021 Accepted: July 28, 2021 Published Online: August 14, 2021

\begin{abstract}
Background. The block problem in this study is the main part of the creative thinking instrument designed as an open-ended task that stimulates students to think creatively which will be analyzed based on the category of creative thinking. The research aims to analyze students' creative thinking in solving block problems. Based on the results of the study, 3 aspects of creative thinking categories will be analyzed, namely fluency, flexibility, and originality. This research was conducted in Junior High School with subject criteria that could solve open-ended problems. The research method used qualitative by giving open-ended assignments accompanied by think-aloud and interview guidelines. Data analysis used descriptive analysis in accordance with qualitative research with triangulation of methods, and theories. The results showed that there were 3 subjects selected based on the completeness of the data from the think-aloud, interviews, and work results so that $\mathrm{S} 1$ was determined as the subject of the fluency category, S2 as the subject of the flexibility category, and S3 as the subject of the originality category. Based on the results of the study, the subject of fluency solved the problem in a short time then the answers produced varied, but with the same strategy, the subject of flexibility found various answers with various strategies, and the subject of originality produced answers that were different and unique from other subjects.
\end{abstract}

Keywords: Creative Thinking, Fluency, Flexibility, Originality, Cuboid Problems.

(c) (1) () 2021. The Author(s). This open access article is distributed under a Creative Commons Attribution (CC BY-SA) 4.0 license.

Anisah Saida

anisahsaida098@gmail.com

Muhammad Ikram

muhammad.ikram@uncp.ac.id

Salwah

salwah@uncp.ac.id

1 Universitas Cokroaminoto Palopo, Makasar, Indonesia 


\section{INTRODUCTION}

Optimal education of the ability to think creatively is closely related to the way of teaching. The most important element in teaching is directing students to learn (Azhari, 2014). Weak creative thinking skills of students can be caused by several factors, one of which is the learning process carried out. Mathematics learning must involve students actively and facilitate students to be able to use their creative thinking skills. Another thing that hinders students' creative thinking skills is the fixation of students' answers on materials or concepts in books and other people's opinions, so they cannot develop properly (Abdurrozak, 2016, Ikram et al., 2021).

Creative thinking is a process that can provide different ideas or ideas and become new knowledge and needed answers. Mathematics learning needs to be designed so that it has the potential to develop students' creative thinking skills. The development of creative thinking skills needs to be done in line with the development of how to measure it. Creative thinking that implies perseverance, personal discipline, and attention involves mental activities such as asking questions, considering new information and unusual ideas with an open mind, making connections, especially between similar things, linking one another. with others freely, applying imagination to any situation that generates new and different ideas, and paying attention to intuition (Sari, 2017). The level of creative thinking is also very influential on student achievement (Rahman, 2012). Several researchers have studied creative thinking with various meanings. Creative thinking is a way of thinking that produces something new in concepts, understanding, inventions, and works of art and provides various possible answers based on the information provided (Moma, 2016). Creative thinking ability can also be interpreted as the ability to generate a possibility, idea, thought, and combine concepts or ideas. Furthermore, another understanding of creative thinking is the formation of an alternative point of view that results in innovative designs or following new things to a problem to produce an idea and describe ideas with different perspectives (Asari, 2016).

One of the materials that can encourage children to think creatively is through block problems. This is because the problem can be designed by involving open problems. In addition to many research results that find students fail or make mistakes in solving block problems, there is also a lack of student creativity in solving block problems. The arrangement of creative thinking in working on each question is needed in training creativity for students so that students can build and implement each new idea. The level of creative imagination is determined by the results of creative thinking produced in every discovery, idea, and is not limited to producing something useful. Creativity in thinking is very influential on the learning process (Suherman, 2015, Febryliani et al., 2021). Students always have to be active in solving a given problem, namely continuing to look for ideas so that the results of these ideas can be communicated and proven to others to develop their creativity.

Based on these studies, opinions about creative thinking, and the researchers' initial findings made the researchers want to know how students think creatively in solving block problems. This is reinforced by the researchers' initial findings when providing instruments for junior high school students, where it was found that there would be someone who showed creative thinking in solving block problems. The instrument given to students is an open-ended task of one number regarding the block problem. Through the assigned tasks, students will be trained in finding ideas to solve problems creatively and finding new concepts for the questions given. Students' creative thinking ability can be measured through the method of completion used, the ability to analyze questions, and the results obtained whether or not following the actual answer to the question. 
The ability to think creatively in mathematics refers to the notion of creative thinking ability in general. Creative thinking is thinking that is original, reflective, and produces a complex product. The ability to think involves synthesizing ideas, building new ideas and determining their effectiveness. This understanding does not mention that creative thinking is only intuitive, separated from logical thinking, nor does it explicitly state that creative thinking is a synthesis or combination of intuitive logical and divergent thinking. Creative thinking is a unit in which logical and divergent thinking processes support each other (Purwaningrum, 2016, Hastuti et al, 2021). Divergent thinking focuses more on variations in different answers to a question so that answers are subjective. Students' creative thinking skills can be developed by reading literature by critically studying the proof of a theorem, the idea of working on problems, especially questions that are quite difficult to work on. Students reading literature will improve students' insights in solving problems, finding problems, and so on.

Based on some of the descriptions above regarding creative thinking, it can be concluded that creative thinking is a cognitive ability to solve divergent problems needed by students in solving a problem and can make students find new combinations of ideas or ideas from a problem. The ability to think creatively is also based on a person's ability to generate new ideas that will produce original and complex products and involve synthesizing ideas and determining their effectiveness. Based on the definition of creative thinking, several definitions of creative thinking, creative thinking skills emphasize three aspects as indicators, namely fluency, flexibility, and originality. Fluency is fluency in thinking that causes a person to generate many ideas, answers and obtain more than one solution to a given problem. A person is said to have the ability to think fluently if he can solve problems quickly without having to think long and with creative ideas. Flexibility is defined if you have a variety of answers to a problem. This refers to the ability of students to generate ideas or solutions with different patterns of answer thinking. Students are expected to explain and describe each method used in the answers as student productivity in determining various perspectives on solving each problem. Originality is what causes someone to generate unique new ideas and find new combinations of ideas from a given problem. When students can provide more than one interesting idea, it can be said that they have originality in thinking. Answers refer to the ability of students to find answer ideas that are new, different from others, and are correct. The level of student creativity can be measured through the resulting solution. Students can provide answers through their thoughts so that this becomes a benchmark that will be explored in measuring the level of creative thinking that students have.

\section{METHOD}

\subsection{Context}

The type of research used in this research is qualitative research. Qualitative research is an approach to explore and understand a central phenomenon where researchers conduct interviews or provide questions in the form of questionnaires to research subjects by asking several questions related to the questions or materials given either in the process of answering or how the subject can determine the answer (Fitrah, 2010). 2018). This study aims to analyze the creative thinking process of students regarding the block problem. The instrument given is in the form of open-ended task questions accompanied by a think-aloud. Students will determine how to solve the problem by providing answers and then the researcher will analyze the extent to which students' creative 
thinking abilities are generated from the variety of answers produced and the steps in answering. Students will be asked to provide results through interviews, the variety of answers produced greatly affects the level of creativity students have. One of the problems researchers have in this research instrument is that students are given questions in the form of open-problem questions by determining the surface area of a beam.

\subsection{Participants}

This research was conducted by determining the selected subjects based on the criteria of creative thinking and completeness of think-aloud data, interviews, and work results. The research subjects in this study were students from class VIII of Junior High School. This is because: (1) the student has gone through a series of learning processes about block material; (2) the student is categorized as having been able to express or communicate his ideas in solving problems. Subject selection is based on answers from open-ended, think-aloud, and interviews conducted to prospective subjects who successfully answer the problem correctly on the assignment. Then one subject was selected based on the category of creative thinking indicators and the completeness of the results of thinkaloud, interviews, and work results. Many prospective subjects did think-aloud as many as 11 prospective subjects, with 7 out of 11 showed indications of solving problems involving creative thinking. While 4 of them do not show the creative thinking process. Furthermore, the 7 prospective subjects were categorized into 3 categories: fluency, flexibility with 1 subject, and originality with 1 subject. The presentation of the fluency result data was selected based on the completeness of the think-aloud data, interviews, and work results so that $\mathrm{S1}$ was determined as the subject of the fluency category, S2 as the flexibility category, and S3 as the subject of the originality category.

\section{Table 1 Participants Information}

\section{Subject}

\begin{tabular}{lll}
\hline $\begin{array}{l}\text { S1 (subject } \\
\text { fluency) }\end{array}$ & 1. & $\begin{array}{l}\text { S1 completes the task in } 3 \text { minutes } 32 \text { seconds. } \\
\text { S1 uses many ideas with the same strategy }\end{array}$ \\
\hline $\begin{array}{l}\text { S2 (subject } \\
\text { flexibility) }\end{array}$ & 1. & $\begin{array}{l}\text { S2 generates many ideas and answers with different } \\
\text { strategies. }\end{array}$ \\
\hline $\begin{array}{l}\text { S3 (subject } \\
\text { originality) }\end{array}$ & 1. & S3 produces a different and unique way of solving problems \\
\hline
\end{tabular}

\section{Instrumen to Collect Data}

The instrument used is in the form of giving open-ended assignments accompanied by think-aloud and interview guidelines. The author presents several questions on an open-ended task related to the block problem.

\section{Open-ended Task}

The open-ended task given is in the form of block material questions used to obtain data on indicators of creative thinking whether the student can meet the fluency, flexibility, and originality categories. Based on the preliminary study results, one of the problems that can stimulate students 
in creative thinking is the block problem. The instrument questions given to students can be seen in Table 3 below.

Tabel 2. Instrumen Task

\section{Open-ended Task}

A block with volume $960 \mathrm{~cm}^{3}$. What are the possible surface areas that can be obtained from this volume?

Based on the problems listed in the table above, students are asked to determine the maximum possible surface area obtained from the problem. The process of solving the problem is how students determine the length, width, and height of the beam and then find the surface area of the value obtained. The way students solve these problems greatly influences the researcher's assessment of the indicators of creative thinking, namely fluency, flexibility, and originality.

\subsection{Interview Guidelines}

Interviews were conducted to strengthen the researcher's assessment of students' creative thinking abilities that were not reached or missed during working on open-ended tasks involving think-aloud. Students are asked to explain based on understanding during working on open-ended tasks, to be analyzed based on their level of creative thinking in terms of fluency, flexibility, and originality. The interview process allows researchers to more easily conclude the extent to which students' creative abilities are based on indicators of creative thinking. Therefore, students are expected to answer all interview questions based on what they experienced when solving the given problem.

The validation of the interview guide sheet is directed at the interview guide, which makes it possible to reveal the subject's creative thinking process. The guidelines included in the instrument have been previously consulted with the supervisor. The questions made by the researcher aim to be a guide in asking questions to prospective subjects related to the given problem, as well as making it easier for prospective subjects to categorize based on creative thinking indicators as supporting think-aloud data. Based on the validation results, the interview guide developed by the researcher has been declared good. The results are shown in the following table.

\begin{tabular}{l} 
Table 3. Interview Guidelines \\
\multicolumn{1}{c}{ Questions } \\
What do you understand from this \\
question? \\
\hline Why is it so easy for you to answer this \\
question? \\
\hline How did you get to that answer? \\
\hline How can you be sure that your answer is \\
correct? \\
\hline Is there another way to solve the problem \\
and how do you do it that way? \\
\hline Where did you get that idea from? \\
\hline What do you understand from this \\
question? \\
\hline How to tone to get the answer? \\
\hline How can you be sure that the answer is \\
correct?
\end{tabular}


Is there another way and how do you do it

that way?

Where did you get that method from?

How do you think about this strategy?

Originality (Originality of Thinking)

\subsection{Data Analysis}

In the data analysis process in this study, researchers used descriptive data analysis according to the type of qualitative research. The data was collected from open-ended assignments accompanied by think-aloud, interview data, and student work. This study aims to describe students' creative thinking analysis based on creative thinking indicators regarding the block problem. The qualitative data analysis procedure, in general, is identification and selection, a description of the phenomenon in general, and the preparation stage regarding the data analysis carried out (Wijaya, 2018).

\section{Table 4 Result of Data Analysis}

\begin{tabular}{ll}
\hline \multicolumn{1}{c}{ Category of Subjek } & \multicolumn{1}{c}{ The character of the Subject } \\
\hline Fluency & \begin{tabular}{l} 
Subjects need fast time in solving problems. \\
\cline { 2 - 2 }
\end{tabular} \\
\hline Flexibility & $\begin{array}{l}\text { Subjects gave various answers with the same } \\
\text { strategy (one point of view). }\end{array}$ \\
& $\begin{array}{l}\text { The subject completes by producing more than } \\
\text { one solution with different strategies }\end{array}$ \\
\cline { 2 - 2 } & $\begin{array}{l}\text { The subject takes a long time to understand the } \\
\text { problem }\end{array}$ \\
\hline Originality & $\begin{array}{l}\text { The subject finishes with a different angle of view } \\
\text { from other subjects }\end{array}$ \\
\cline { 2 - 2 } & $\begin{array}{l}\text { The subject takes a long time to understand the } \\
\text { problem }\end{array}$ \\
\hline
\end{tabular}

\section{RESULT AND DISCUSSION}

\subsection{RESULTS}

Based on the data obtained from think-aloud, interviews, and work results, it can be seen that $\mathrm{S1}$ is categorized as a fluency subject due to several things. First, $\mathbf{S 1}$ answered the questions in a short time of 3 minutes 32 seconds in the think-aloud process. It can be seen that $\mathrm{S} 1$ understands the question so that he can re-explain what has been written during the think-aloud process. S1 directly focuses on the problem so that S1 gets the right answer and is worth it. Second, S1 has another solution from the resulting answer, but the other answer is simply manipulating the numbers in the same way to determine the surface area. It can be seen that S1 also strongly believes that the answer is correct, and there is no need to check the answers. 
Based on the data obtained, S2 did the work for a fairly long time, namely 4 minutes 2 seconds, but $S 2$ could produce methods from different perspectives, so problem-solving did not only use one method. Based on the results of the think-aloud exposure, interviews, and the results of Master's work, it is categorized as flexibility because Masters can produce more than one answer with different strategies, both of which are correct. Masters understands what has been written in the think-aloud process, so it is effortless to explain again in the interview process.

Based on the data obtained from the results of think-aloud, interviews, and the results of S3 work, it is categorized as a subject of originality, because S3 can produce answers that are different from other subjects and have the correct value. S3 does the task very carefully and immediately believes in the answers produced without re-checking the answers. This is evidenced by researchers exploring deeper through the interview process. S3 can provide answers by what is stated in the results of think-aloud and work results. The presentation of S3's work is unique and detailed, even though the processing time is quite long, 7 minutes 30 seconds. Therefore, S3 is categorized as a subject of originality.

\subsection{Discussion}

The researchers described think-aloud data, interviews, and work results to track students' creative thinking based on the research data. The findings obtained include 1) subject of fluency category, 2) subject of flexibility category, 3) subject of originality category. The following is an explanation of each section of the findings:

\section{Subject Category Fluency}

Fluency subject takes a short time to solve the problem. This is in line with Abdurrozak (2016) findings that students who think fluency can solve problems quickly without having to think long in finding creative ideas. In addition, the subject's ability to solve problems in a short time is also based on the dual-process theory by Evans (2009) that if the subject works in a short time, it is categorized into system 1. Based on the definition of system 1, it is explained that the subject of fluency has a high processing capacity and only focuses on one point of view. The thought process of the fluency subject is considered to have an experience-based way of answering that produces the usual responses (Sowden 2015). So it can be said that the subject of fluency has understood the information on the problem by using previous experience to answer the problem. This happens when the subject recalls the answer information from the results of previous experiences. Fluency subjects have an intuitive way of thinking that generates ideas or ideas quickly and precisely by combining data that has been obtained implicitly (based on the form of experience). Based on the research data, the fluency subject did not verify the answer. The thing that causes the subject not to verify the answer is the subject's lack of awareness in observing the problem questions so that it is only possible to write down the operations to be used. Regarding the way of thinking, the subject of fluency is categorized using a divergent way of thinking. The subject is only said to be creative who can provide possible answers based on existing problems but cannot use adaptation to change the idea of solving a problem.

Based on the answers generated, the subject of fluency produced various answers but with the same strategy. This is in line with Siswono (2016) findings that problem solving will be said to be diverse if the answers look different but still follow a certain pattern. The subject of fluency is only fluent in working time but does not develop his ideas in solving problems. The resulting settlement process is only based on a previously obtained point of view, so it can be said that the subject of 
fluency has not been able to develop a solution from another point of view. The subject of fluency still relies on guidelines according to what is presented in the problem, with a pattern of solving that is still general but can understand the problem quickly. Subjects are said to be fluent if they can understand the problem and the answers given are correct. This is in line with Lisliana's (2012) research that subjects who meet the fluency indicator can understand the problem and develop a problem-solving plan.

\section{Subject Category Flexibility}

Flexibility category subjects require a relatively long time in solving problems. Based on the dualprocess theory proposed by Evans (2009), the subject who works on the system 2 process is described as having a slow, controlled, and analytical process. Fluency subjects tend to be more careful in working on problems and have normative and rational abilities that can correlate with their cognitive abilities. The work process is slow because the subject flexibility thinking process leads to a process that is carried out analytically to produce new ideas that are different from other ideas that have been generated. This is in line with Faizah's research (2016) that flexible subjects always try to observe problems from different perspectives to change the concept used to be different from the initial concept. The subject flexibility perspective focuses on every possible pattern that will be generated so that the subject is creative and analytical and pays attention to the number of categories of problems that will be responded to.

Based on the study results, the subject of flexibility is a subject that is rarely found. This is because the answers generated by the subject are based on convergent thinking. The subject flexibility thinking pattern is related to applying more accurate completion techniques and always looking for new or different solutions. Based on the understanding of flexibility according to Faizah's research (2016), a subject is said to be flexible if he can change the concept of completion in a different way from the initial concept but produces an answer that has the correct answer value. In accordance with the explanation of the research results, subject flexibility produces different answers with different strategies. The subject of flexibility is always based on the ability to analyze problems so that it produces not only creative answers but also produces various points of view. Although basically, one of the answers produced by subject flexibility is the same as the completion pattern in general.

\section{Subject Category Originality}

Based on the research results, originality subjects tend to use different concepts from other subjects. Originality subject also takes a relatively longer time than other subjects. Based on the dual process theory proposed by Evans (2009), the subject of originality also works on system 2. The responses obtained by the subject during the work process refer to the problem analysis process. The subject solves the problem in a relatively long time, but produces answers that are different from other subjects and are correct. Based on the research data exposure, the originality subject only produced one answer and believed that there were no more answers that could be obtained other than the answers generated. The subject of originality tends to only produce one answer because looking for the second way will firstly raise doubts. Subjects tend to have a less diverse mindset but a more creative point of view. The more creative idea that is meant is the perspective of a different subject, but other than that it is possible that the subject of originality can produce and develop patterns of answers from various points of view. This is based on Fauziah (2016) findings that the subject of originality sees problems from various points of view and solutions that are different from others. 


\section{Other Findings}

Based on the study results, the three subjects did not verify the answers on the open-ended task. This is because the subject tends to be lazy to re-read what has been written. Based on Argarini's findings (2018), subjects who did not re-examine their answers were subjects who had a visual learning style. This learning style, where the subject has paid attention to what he has written during the work process. So there is no need to verify the answer because the resulting answer is believed to be correct.

\section{CONCLUSION}

The research question is "How to Analyze Creative Thinking in Solving Block Problems". Based on the research results, 3 subjects were obtained, namely $\$ 1$ as the subject of fluency, S2 as the subject of flexibility, and S3 as the subject of originality. Based on the study results, fluency subjects solved the problem in a short time then the answers produced varied but with the same strategy. Based on the results of the study, flexibility subjects found various answers with various strategies. Based on the study results, originality subjects produced answers that were different and unique from other subjects.

\section{LIMITATIONS AND FUTURE RESEARCH}

One of the shortcomings in this study is that students are still not familiar with think-aloud so that it becomes a limitation for researchers in obtaining data. Based on the results of the study, each subject obtained did not check the answers. So, for further research, it is recommended to examine the subject to re-verify the answers to the problems given. It was found that several subjects failed in creative thinking research, so it is recommended for further research to examine the causes of student failure in carrying out creative thinking processes. The research process also found that the subject was less familiar with open-ended assignments, so further research is recommended to develop tasks that support the learning process in the classroom.

\section{Author Identity}

Anisah Saida

Email: anisahsaida098@gmail.com

ORCID ID:

Muhammad Ikram

Email: : muhammad.ikram@uncp.ac.id

ORCID ID: http://orcid.org/0000-0002-3763-4299

Salwah

Email: salwah@uncp.ac.id

ORCID ID:

\section{Conflict of Interest}

The authors state there is no conflict of interest

\section{Citation information}


Cite this article as: Saida, A, Ikram, M, \& Salwah, .Analysis of Students' Creative Thinking in Solving Cuboid Problems. International Journal of Progressive Mathematics Education. 1(2)19-32. https://doi.org/10.22236/ijopme.v1i1.7307

\section{REFERENCES}

Abdurrozak, R., \& Jayadinata, A. K. (2016). Pengaruh Model Problem Based Learning Terhadap Kemampuan Berpikir Kreatif Siswa. Jurnal Pena IImiah, 1(1), 871-880.

Agustina, W., \& Noor, F. (2016). Hubungan hasil belajar dan tingkat berpikir kreatif siswa dalam pembelajaran matematika. Math Didactic: Jurnal Pendidikan Matematika, 2(3), 191-200.

Andiyana, M. A., Maya, R., \& Hidayat, W. (2018). Analisis kemampuan berpikir kreatif matematis siswa smp pada materi bangun ruang. JPMI (Jurnal Pembelajaran Matematika Inovatif), 1(3), 239-248.

Arifanti, D. R., \& Raupu, S. (2021). Meningkatkan Pengetahuan Siswa Tentang Sistem Persamaan Linear Dua Variabel (SPLDV) Melalui Model Pembelajaran Kooperatif. Kognitif: Jurnal Riset HOTS Pendidikan Matematika, 1(1), 22-33. https://doi.org/10.51574/kognitif.v1i1.8

Argarini, D. F. (2018). Analisis pemecahan masalah berbasis Polya pada materi perkalian vektor ditinjau dari gaya belajar. Matematika Dan Pembelajaran, 6(1), 91-100.

Asari, A. R. (2016). Variasi Konstruk Dalam Pembelajaran Matematika. KARYA DOSEN Fakultas Matematika dan IPA UM.

Awwalin, J. (2019). Kemampuan Berpikir Kreatif Siswa Kelas Viii pada Materi Kubus dan Balok Melalui Strategi Pembelajaran Time Token Student Facilitator and Explaining. Jurnal Pendidikan Matematika (Jpm), 4(1), 09-14.

Azhari, A., \& Somakim, S. (2014). Peningkatan kemampuan berpikir kreatif matematik siswa melalui pendekatan konstruktivisme di kelas VII sekolah menengah pertama (SMP) negeri 2 Banyuasin III. Jurnal Pendidikan Matematika Sriwijaya, 8(1), 1-12.

Evans, J. S. B. (2009). How many dual-process theories do we need? One, two, or many?

Faizah, U. (2018). Profil kemampuan berpikir divergen siswa dalam menyelesaikan masalah open ended (Doctoral dissertation, UIN Sunan Ampel Surabaya).

Fajriah, N., \& Asiskawati, E. (2015). Kemampuan Berpikir Kreatif Siswa Dalam Pembelajaran Matematika Menggunakan Pendekatan Pendidikan Matematika Realistik DiSMP. EDUMAT: Jurnal Pendidikan Matematika, 3(2).

Febryliani, I., Umam, K., Soebagjoyo, J., \& Maarif, S. (2021). Kecemasan Siswa Sekolah Menegah Atas dalam Menyelesaikan Masalah pada Materi Program Linier dalam Praktek Kelas Virtual. Kognitif: Jurnal Riset HOTS Pendidikan Matematika, 1(1), 34-52. https://doi.org/10.51574/kognitif.v111.12

Fitrah, M. (2018). Metodologi penelitian: penelitian kualitatif, tindakan kelas \& studi kasus. CV Jejak (Jejak Publisher).

Hastuti, E. S., Umam, K., Eclarin, L., \& Perbowo, K. S. (2021). Kecemasan Siswa Sekolah Menengah Pertama Dalam Menyelesaikan Masalah SPLDV Pada Kelas Virtual. International Journal of Progressive Mathematics Education, 1(1), 63-84. https://doi.org/10.22236/ijopme.v1i1.6914

Happy, N., \& Widjajanti, D. B. (2014). Keefektifan PBL ditinjau dari kemampuan berpikir kritis dan kreatif matematis, serta self-esteem siswa SMP. Jurnal Riset Pendidikan Matematika, 1(1), 48-57. 
Huda, N., \& Kencana, A. G. (2013). Analisis kesulitan siswa berdasarkan kemampuan pemahaman dalam menyelesaikan soal cerita pada materi kubus dan balok di kelas VIII SMP Negeri 30 Muaro Jambi. Prosiding Semirata 2013, 1(1).

Ikram, M., \& Parta, I. N. (2021). Analysis of The Occurrence of Reversible Reasoning for Inverse Cases: A Case Study on The Subject Adjie. International Journal of Progressive Mathematics Education, 1(1), 1-15. https://doi.org/10.22236/ijopme.v1i1.6635

Irawan, D. (2015). Analisis kemampuan berpikir kreatif matematis dan kemandirian melalui pembelajaran model 4K ditinjau dari gaya belajar siswa kelas VII (Doctoral dissertation, Universitas Negeri Semarang).

Islami, F. N., Putri, G. D., \& Nurdwiandari, P. (2018). Kemampuan Fluency, Flexibility, Orginality, Dan Self Confidence Siswa SMP. JPMI (Jurnal Pembelajaran Matematika Inovatif), 1(3), 249-258.

Ismara, L. (2017). Kemampuan berpikir kreatif matematis siswa dalam menyelesaikan soal open ended di SMP. Jurnal Pendidikan dan Pembelajaran Khatulistiwa, 6(9).

Lisliana, L., Hartoyo, A., \& Bistari, B. (2012). Analisis Kemampuan Berpikir Kreatif Siswa dalam Menyelesaikan Masalah pada Materi Segitiga di SMP(Doctoral dissertation, Tanjungpura University).

Moma, L. (2016). Pengembangan instrumen kemampuan berpikir kreatif matematis untuk siswa SMP. Delta-Pi: Jurnal Matematika dan Pendidikan Matematika, 4(1).

Nasution, L. M. (2017). Statistik deskriptif. Hikmah, 14(1), 49-55.

Nurjanatin, I., Sugondo, G., \& Manurung, M. M. (2017). Analisis kesalahan peserta didik dalam menyelesaikan soal cerita pada materi luas permukaan balok di kelas VIII-F semester II SMP Negeri 2 Jayapura. Jurnal IImiah Matematika dan Pembelajarannya, 2(1).

Octaviani, K. D., Indrawatiningsih, N., \& Afifah, A. (2021). Kemampuan Visualisasi Spasial Siswa Dalam Memecahkan Masalah Geometri Bangun Ruang Sisi Datar. International Journal of Progressive Mathematics Education, 1(1), 27-40. https://doi.org/10.22236/ijopme.v1i1.6583

Purwaningrum, J. P. (2016). Mengembangkan kemampuan berpikir kreatif matematis melalui discovery learning berbasis scientific approach. Refleksi Edukatika: Jurnal IImiah Kependidikan, 6(2).

Raco, J. (2018). Metode penelitian kualitatif: jenis, karakteristik dan keunggulannya.

Rahman, R. (2012). Hubungan antara self-concept terhadap matematika dengan kemampuan berpikir kreatif matematik siswa. Infinity Journal, 1(1), 19-30.

SAFFAWATI, D. (2019). PROSES BERPIKIR KREATIF SISWA DALAM MENYELESAIKAN SOAL OPEN ENDED PADA MATERI KUBUS DAN BALOK KELAS VIII DI MTS AL MA'ARIF TULUNGAGUNG TAHUN AJARAN 2017/2018.

Saparwadi, L. (2014).Efektivitas Pembelajaran Aljabar dengan Model Elaborasi Terhadap Peningkatan Keterampilan Berpikir Kreatif Mahasiswa. Beta:JumalTadrisMatematika, 7(2),98-107.

Sari, A., Ikhsan, M., \& Saminan, S. (2017). Proses berpikir kreatif siswa dalam memecahkan masalah matematika berdasarkan model Wallas. Beta: Jurnal TadrisMatematika, 10(1),18-32.

Sari, W. O. (2020). Pengaruh Pendekatan Pembelajaran Matematika Realistik Terhadap Kemampuan Berpikir Kreatif pada Materi Balok. Jurnal Pendidikan Edutama.

Siswono, T. Y. E. (2016). Berpikir Kritis dan Berpikir Kreatif sebagai Fokus Pembelajaran Matematika. In Seminar Nasional Matematika dan Pendidikan Matematika (pp. 11-26). 
Suherman, S. (2015). Kreativitas siswa dalam memecahkan masalah matematika materi pola bilangan dengan Pendekatan Matematika Realistik (PMR). Al-Jabar: Jurnal Pendidikan Matematika, 6(1), 8190 .

Wijaya, H. P. I., Sujadi, I., \& Riyadi, R. (2016). Kemampuan Komunikasi Matematis Siswa Sesuai dengan Gender Dalam Pemecahan Masalah Pada Materi Balok Dan Kubus (Studi Kasus Pada Siswa SMP Kelas VIII SMP Islam Al-Azhar 29 Semarang). Jurnal Pembelajaran Matematika, 4(9). 